\title{
The Use of Halophytic Companion Plant (Portulaca oleracea L.) on Some Growth, Fruit, and Biochemical Parameters of Strawberry Plants under Salt Stress
}

\author{
Sema Karakas ${ }^{1}$ * , Ibrahim Bolat ${ }^{2}$ and Murat Dikilitas ${ }^{3}$ \\ 1 Department of Soil Science and Plant Nutrition, Faculty of Agriculture, Harran University, \\ Sanliurfa 63300, Turkey \\ 2 Department of Horticulture, Faculty of Agriculture, Harran University, Sanliurfa 63300, Turkey; \\ ibolat@harran.edu.tr \\ 3 Department of Plant Protection, Faculty of Agriculture, Harran University, Sanliurfa 63300, Turkey; \\ m.dikilitas@harran.edu.tr \\ * Correspondence: skarakas@harran.edu.tr
}

\section{check for} updates

Citation: Karakas, S.; Bolat, I.; Dikilitas, M. The Use of Halophytic Companion Plant (Portulaca oleracea L.) on Some Growth, Fruit, and Biochemical Parameters of Strawberry Plants under Salt Stress. Horticulturae 2021, 7, 63. https://doi.org/10.3390/ horticulturae7040063

Academic Editors: Agnieszka Hanaka, Jolanta Jaroszuk-Ściseł and

Małgorzata Majewska

Received: 10 February 2021

Accepted: 23 March 2021

Published: 26 March 2021

Publisher's Note: MDPI stays neutral with regard to jurisdictional claims in published maps and institutional affiliations.

Copyright: (c) 2021 by the authors. Licensee MDPI, Basel, Switzerland. This article is an open access article distributed under the terms and conditions of the Creative Commons Attribution (CC BY) license (https:/ creativecommons.org/licenses/by/ $4.0 /)$.

\begin{abstract}
Strawberry is a salt-sensitive plant adversely affected by slightly or moderately saline conditions. The growth, fruit, and biochemical parameters of strawberry plants grown under $\mathrm{NaCl}(0,30$, 60 , and $90 \mathrm{mmol} \mathrm{L}^{-1}$ ) conditions with or without a halophytic companion plant (Portulaca oleracea L.) were elucidated in a pot experiment. Salt stress negatively affected the growth, physiological (stomatal conductance and electrolyte leakage), and biochemical parameters such as chlorophyll contents (chl- $a$ and chl- $b$ ); proline, hydrogen peroxide, malondialdehyde, catalase, and peroxidase enzyme activities; total soluble solids; and lycopene and vitamin C contents, as well as the mineral uptake, of strawberry plants. The companionship of P. oleracea increased fresh weight, dry weight, and fruit average weight, as well as the total fruit yield of strawberry plants along with improvements of physiological and biochemical parameters. This study showed that the cultivation of P. oleracea with strawberry plants under salt stress conditions effectively increased strawberry fruit yield and quality. Therefore, we suggest that approaches towards the use of $P$. oleracea could be an environmentally friendly method that should be commonly practiced where salinity is of great concern.
\end{abstract}

Keywords: abiotic stress; strawberry; companion plants; phytoremediation

\section{Introduction}

Salinity is one of the most devastating environmental problems limiting crop productivity and quality in many regions of the world. This problem is more prevalent in arid and semi-arid climatic regions. It affects approximately $20 \%$ of the cultivated and $50 \%$ of irrigated agricultural lands [1,2]. It has now been estimated that 1.5 million hectares of lands have been lost every year due to salinity problems. If salinization goes with this trend, nearly $50 \%$ of cultivable lands will be lost by the mid-point of this century [3,4].

Salinity negatively affects plant growth in terms of osmotic, ionic, and nutrient imbalance [5]. These disorders cause oxidative stress on plants. If plants cannot get enough water under high salt stress, turgor pressure significantly decreases, and thus the closure of the stomata of plants becomes inevitable to conserve water [6]. This significantly affects the photosynthetic capacity of plants. Ionic toxicity, on the other hand, inhibits cellular metabolism and biochemical pathways. For example, $\mathrm{Na}^{+}$ions at the root cell disturb enzymatic activities and inhibit the uptake of other minerals such as $\mathrm{K}^{+}$and $\mathrm{Ca}^{++}$[7]. The high accumulation of $\mathrm{Na}^{+}$and $\mathrm{Cl}^{-}$ions result in many morphological, physiological, molecular, and biochemical pathways in plants. Due to disturbed mechanisms in plants, $\mathrm{NaCl}$ stress leads to the development of leaf chlorosis and necrosis, as well as the loss of quality in crops. As a consequence, the assimilation of carbohydrates and sugars allocated 
for fruit development is significantly reduced due to stress development and defense mechanisms $[8,9]$.

Plants can be divided into halophytes and glycophytes as responses to salinity stress. Most glycophytes are salt-sensitive, even at low concentrations, while halophytes are highly salt-tolerant plants, which enables them to survive and thrive in extremely saline environments $[10,11]$. Salt ions have to be taken up by halophytes and deposited in the vacuoles of leaf or root tissues or in separate organelles. In general, salt secretion takes place through the shedding of salty leaves and salt glands or specialized leaf cells [12] Most halophytes are able to survive by maintaining negative water potential under extreme salt concentrations. Therefore, a true halophyte is considered to maintain its viability and complete the life cycle at $\mathrm{NaCl}$ levels between 200 and $1000 \mathrm{mmol} \mathrm{L}^{-1}$. These concentrations are very close to the concentrations of seawater level. Some halophytes, on the other hand, tolerate much higher concentrations of $\mathrm{NaCl}[10,13]$. Halophytes such as Atriplex spp., Chenopodium spp., Portulaca spp., Suaeda spp., and Salsola spp. uptake salt ions through their roots and store them in their leaves. It is quite possible that these plants could be used as companion plants with crop plants, especially salt-sensitive glycophytes, to reduce the negative effects of $\mathrm{NaCl}$ through the uptake of toxic ions [14,15]. For example, Portulaca oleracea L. (purslane) (which is a member of Portulacaceae), is a drought- and salt-tolerant annual plant. The plant is a promising crop species in saline-alkali soils [16,17]. Moreover, P. oleracea could effectively absorb salts from soil media to remediate saline-alkali soils [18]. Previous studies have investigated the effects of salinity on P. oleracea growth. For example, Grieve and Suarez [19] evaluated P. oleracea responses with saline irrigation, and they showed that the plant could survive at a salinity of $28.5 \mathrm{dS} \mathrm{m}^{-1}$. The authors further elucidated the performances of salt-tolerant halophyte species of P. oleracea and Salsola soda against increasing $\mathrm{NaCl}$ levels. They reported that P. oleracea and $S$. soda seeds were effectively germinated between 250 and $350 \mathrm{mmol} \mathrm{L}^{-1} \mathrm{NaCl}$ levels [20].

Strawberry is an economically important fruit crop that is globally cultivated. It belongs to the Fragaria genus in Rosaceae family, which contains 23 species [21,22]. The popularity of strawberry fruit crops is increasing in the world due to increasing consumption. Its popularity is also increasing along with the generation of new varieties. Strawberry cultivation has therefore become an important greenhouse and open field crop in the Mediterranean area, although drought and salinity have played significant roles in limiting crop production [23,24].

Strawberry is considered to be sensitive to $\mathrm{NaCl}$ salinity due to increased osmotic pressure and $\mathrm{Na}^{+}$or $\mathrm{Cl}^{-}$ion toxicity. $\mathrm{NaCl}$ salinity not only reduces the crop yield but also deteriorates the quality parameters in many crops, including strawberries $[25,26]$.

In the present study, we elucidated the effects of different $\mathrm{NaCl}$ concentrations on strawberry plants grown with or without the halophytic companion plant $P$. oleracea $\mathrm{L}$. to remediate the physiological and biochemical parameters of strawberry plants.

\section{Materials and Methods}

\subsection{Experimental Design and the Growth of Plants}

The experiment was performed between September 2018 and January 2019 in a semicontrolled greenhouse at the University of Harran, Sanliurfa, Turkey. Fresh strawberry (Rubygem variety) plants were grown alone or in combination with P. oleracea seedlings in 8-L pots containing peat (Klasmann TS 1) under natural light conditions. Peat is a very porous substrate with an excellent water capacity. Its slow degradation rate, high porosity, and high-water holding capacity makes it one of the most commonly used growth medium, especially for saline-related studies in vegetables and ornamental plants $[27,28]$. It has low nutrient values, so it is highly unlikely to affect the mineral uptake of macro and micronutrient elements.

The average temperatures for day and night were $35 \pm 2 / 28 \pm 2{ }^{\circ} \mathrm{C}$ during the course of the experiment. The trial was carried out in a randomized block design. The first group of strawberry plants grown under differing $\mathrm{NaCl}$ conditions $(0,30,60$, and 
$90 \mathrm{mmol} \mathrm{L}^{-1}$ ) was designated as $\mathrm{S}_{0}, \mathrm{~S}_{30}, \mathrm{~S}_{60}$, and $\mathrm{S}_{90}$; the second group of plants grown with $P$. oleracea under the same $\mathrm{NaCl}$ conditions was designated as $\mathrm{SP}_{0}, \mathrm{SP}_{30}, \mathrm{SP}_{60}$, and $\mathrm{SP}_{90}$. Treatments in each group were replicated five times. Seedlings were individually transplanted to the pots. Strawberry seedlings following one week of establishment growth in pots were accompanied with $P$. oleracea seeds that were sown and germinated at a rate of 25 companion plants per pot. After germinations (five weeks), the pots were irrigated with or without salt to the full pot capacity throughout the treatment period (twelve weeks). The plants were fertigated with Hoagland's nutrient solution once a week. The experimental trial from the very beginning of obtaining strawberry seedlings to the end of harvest took five months. The plants were harvested at the optimum stage of physiological maturity for the evaluation of salinity responses (Figure 1).

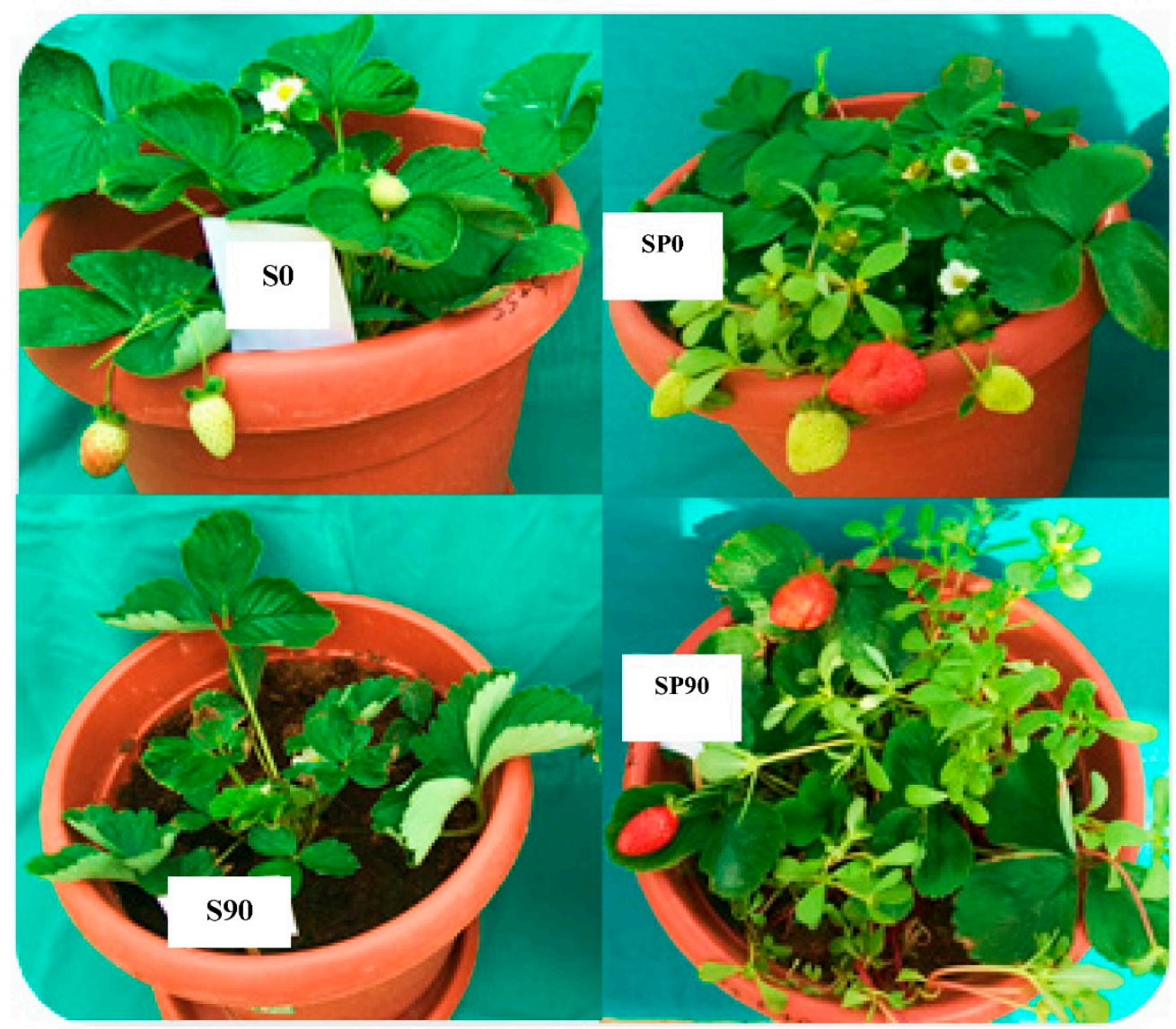

Figure 1. Strawberry plants were grown with or without Portulaca oleracea under different $\mathrm{NaCl}$ conditions.

\subsection{Plant Growth and Fruit Properties}

Strawberry fruits were harvested when $90 \%$ of the fruit surface had reached a fully red color. At the end of the experimental period, total fruit weights were determined and the average fruit yield was calculated.

Plant crown and root fresh weight (Fwt) were analyzed immediately after the harvest. The dry weight (Dwt) of plant organs was determined following the drying of plant samples at $70^{\circ} \mathrm{C}$ until a constant weight.

Total soluble solids (TSS) were assessed from the fruit juice with a hand refractometer. The results are expressed in percent (\%) Catania et al. [29].

The lycopene content of strawberry fruits was assessed according to the method of Barrett and Anthon [30] with minor modifications [31]. One gram of strawberry fruit was homogenized with $10 \mathrm{~mL}$ of an ethanol:hexane solution (4:3). The mixture was then 
centrifuged at $10,000 \times g$ for $10 \mathrm{~min}$ at room temperature. The supernatant $(100 \mu \mathrm{L})$ was added to $7 \mathrm{~mL}$ of the ethanol:hexane solution (4:3) mixture and vortexed. After $1 \mathrm{~h}$ of incubation at room temperature, $1 \mathrm{~mL}$ of $\mathrm{H}_{2} \mathrm{O}$ was added to the tubes and vortexed. The tubes were incubated in the dark to form two different phases. The top phase was taken and read at $503 \mathrm{~nm}$ against a hexane blank with a UV microplate spectrophotometer (Epoch, SN: 1611187, Winooski, VT, USA). The lycopene content was calculated according to the following formula (Equation (1)).

$$
\mu \mathrm{g} \text { Lycopene } \mathrm{g}^{-1} \mathrm{Fwt}=\frac{A_{503} \times 2.7}{172 \times 0.1} \times 537
$$

where $537 \mathrm{~g} / \mathrm{mole}$ is the molecular weight of lycopene, $2.7 \mathrm{~mL}$ is the volume of the hexane layer, $172 \mathrm{mmol}^{-1}$ is the extinction coefficient for lycopene in hexane, and $0.1 \mathrm{~g}$ is the weight of the strawberry.

The vitamin C content of strawberry fruits was assessed according to the method of $\mathrm{Oz}$ [32] with small modifications [31]. Strawberry fruits (5 g) were extracted with $25 \mathrm{~mL}$ of oxalic acid. The mixture was centrifuged at $10,000 \times \mathrm{g}$ for $10 \mathrm{~min}$. Then, $1 \mathrm{~mL}$ of this mixture was added to $7 \mathrm{~mL}$ of a $1 \%$ oxalic acid solution and $8 \mathrm{~mL}$ of a dye reagent. The dye reagent was prepared according to the recipe of [31]. The mixture was filtered through Whatman No.2 filter paper and diluted to $100 \mathrm{~mL}$ with deionized $\mathrm{H}_{2} \mathrm{O}$. Then, $25 \mathrm{~mL}$ of this solution were taken and diluted to $500 \mathrm{~mL}$ with deionized $\mathrm{H}_{2} \mathrm{O}$, vortexed, and kept at $4{ }^{\circ} \mathrm{C}$ until use. The mixture was once more vortexed before measurement at $518 \mathrm{~nm}$ against the oxalic acid and dye mixture with a UV microplate spectrophotometer (Epoch, SN: 1611187, Winooski, VT, USA).

Electrolyte leakage (EL) was assessed following the method of Lutts et al. [33] using leaf discs for each treatment. Fully expanded young leaves were cleaned three times with deionized $\mathrm{H}_{2} \mathrm{O}$ to remove dust and surface-adhered electrolytes. Leaf discs were placed in closed vials containing $10 \mathrm{~mL}$ of $\mathrm{H}_{2} \mathrm{O}$ and incubated at $25^{\circ} \mathrm{C}$ on a rotary shaker for $24 \mathrm{~h}$; subsequently, the electrical conductivity of the solution $\left(\mathrm{EC}_{1}\right)$ was measured. The final electrical conductivity $\left(\mathrm{EC}_{2}\right)$ was determined following the autoclaving of the leaf samples at $120^{\circ} \mathrm{C}$ for $20 \mathrm{~min}$. Leaf samples were then equilibrated at $25^{\circ} \mathrm{C}$, and the EL was calculated as follows (Equation (2)).

$$
E L(\%)=\frac{E C 1}{E C 2} \times 100
$$

Stomatal conductivity (SC) was determined on the youngest fully expanded leaves on the upper branches of the strawberry plants with a leaf promoter (SC-1) at midday. Measurements were performed by clamping the leaves in the leaf chamber. The actual vapor flux from the leaf through the stomata is expressed as $\mathrm{mmol} \mathrm{m}^{-2} \mathrm{~s}^{-1}$, following the work of Karlidag et al. [34].

\subsection{Biochemical Parameters}

Strawberry plant leaf chlorophyll content (Chl- $a$ and Chl- $b$ ) was extracted following the method of Arnon [35] with minor modifications [31]. A sample of the fresh leaf ( $0.5 \mathrm{~g})$ was homogenized with $10 \mathrm{~mL}$ of an acetone:water $(80 / 20, v / v)$ mixture and filtered through Whatman No.2 filter paper and then put into the dark tubes. The Chl- $a$ and Chl- $b$ contents of the filtrate was measured with a UV microplate spectrophotometer (Epoch, SN: 1611187, Winooski, VT, USA) at 663 and $645 \mathrm{~nm}$, respectively, against an $80 \%$ acetone blank. The findings were expressed as $\mathrm{mg} \mathrm{L}^{-1}$ and calculated as $\mathrm{mg} \mathrm{g}^{-1}$ Fwt.

The proline concentration was determined following the method of Bates et al. [36] with minor modifications [31]. Leaf samples $(0.5 \mathrm{~g})$ were extracted with $10 \mathrm{~mL}$ of $3 \% \mathrm{w} / \mathrm{v}$ sulphosalicylic acid using a mortar and a pestle. The extract was filtered through Whatman No. 2 filter paper. Then, the $2 \mathrm{~mL}$ filtrate was mixed with $2 \mathrm{~mL}$ of acid-ninhydrin in a test tube and boiled at $100{ }^{\circ} \mathrm{C}$ for $1 \mathrm{~h}$. The reaction was terminated in an ice bath. Then, the mixture was extracted using $5 \mathrm{~mL}$ of toluene. The tubes were vortexed for $20 \mathrm{~s}$ and then 
left for $20 \mathrm{~min}$ at room temperature to achieve two layers of separation. The organic phase was collected, and the absorbance of the extracts was read at $515 \mathrm{~nm}$ using a toluene blank. Proline concentration was made from a standard curve using L-proline (Sigma-Aldrich, Taufkirchen-Germany). The results are expressed as $\mu \mathrm{mol} \mathrm{g}^{-1}$ Fwt.

Hydrogen peroxide $\left(\mathrm{H}_{2} \mathrm{O}_{2}\right)$ levels were assessed following the method of Velikova et al. [37] with small modifications [38]. Leaf samples $(0.5 \mathrm{~g})$ were extracted with $5 \mathrm{~mL}$ of $0.1 \%(w: v)$ trichloroacetic acid (TCA). The extract was centrifuged at 12,000 $\times g$ at $4{ }^{\circ} \mathrm{C}$ for $15 \mathrm{~min}$, and the supernatant $(0.5 \mathrm{~mL})$ was added to $0.5 \mathrm{~mL}$ of a $10 \mathrm{mmol} \mathrm{L}^{-1}$ potassium phosphate buffer ( $\mathrm{pH} 7.0)$ and $1 \mathrm{~mL}$ of a $1 \mathrm{~mol} \mathrm{~L}^{-1}$ potassium iodide. The absorbance was read at $390 \mathrm{~nm}$ in a UV microplate spectrophotometer (Epoch, SN: 1611187, Winooski, VT, USA). The $\mathrm{H}_{2} \mathrm{O}_{2}$ content was expressed as $\mu \mathrm{mol} \mathrm{g}{ }^{-1}$ Fwt.

The malondialdehyde (MDA) content was assessed following the method of Sairam and Sexena [39] with minor modifications [38]. The leaf samples ( $0.5 \mathrm{~g})$ were extracted with $10 \mathrm{~mL}$ of a $0.1 \%(w / v)$ TCA solution. The extract was centrifuged at $10,000 \times g$ for 5 min. Four milliliters of $20 \% v / v$ TCA containing $0.5 \% v / v$ thiobarbituric acid (TBA) was added to $1 \mathrm{~mL}$ of the supernatant. The mixture was kept in boiling water for $30 \mathrm{~min}$, and then the reaction was stopped in an ice bath. The mixture was once more centrifuged at $10,000 \times g$ for $5 \mathrm{~min}$ and then read in a UV microplate spectrophotometer (Epoch, SN: 1611187, Winooski, VT, USA) at 532 and $600 \mathrm{~nm}$. The MDA content was calculated and expressed as nmol g ${ }^{-1}$ Fwt (Equation (3)).

$\operatorname{MDA}\left(\mathrm{nmol} \mathrm{g}^{-1}\right)=\frac{\text { Extract volume }(\mathrm{ml}) \times\left[\left(\mathrm{A}_{532}-\mathrm{A}_{600}\right) /\left(155 \mathrm{mM}^{-1} \mathrm{~cm}^{-1}\right)\right]}{\text { Sample amaunt }(\mathrm{g})} \times 10^{3}$

Catalase enzyme activity (CAT; Enzyme Code. 1.11.1.6) was determined following the method of Milosevic and Slusarenko [40] with minor modifications [38]. Leaf samples $(0.5 \mathrm{~g})$ were extracted with $10 \mathrm{~mL}$ of a $50 \mathrm{mmol} \mathrm{L}^{-1} \mathrm{Na}$-phosphate buffer solution, and then $50 \mathrm{~mL}$ of the extract were added to a $2.95 \mathrm{~mL}$ reaction mixture $\left(50 \mathrm{mmol} \mathrm{L}^{-1} \mathrm{Na}\right.$-phosphate buffer, $10 \mathrm{mmol} \mathrm{L}^{-1} \mathrm{H}_{2} \mathrm{O}_{2}$, and $4 \mathrm{mmol} \mathrm{L}{ }^{-1} \mathrm{Na}_{2}$ EDTA) and read with a UV microplate spectrophotometer (Epoch, SN: 1611187, Winooski, VT, USA) at $240 \mathrm{~nm}$ for $30 \mathrm{~s}$. One CAT unit $(\mathrm{U})$ was defined as an increase in absorbance of 0.1 at $240 \mathrm{~nm}$. The activity is expressed as enzyme unite $\mathrm{mg}^{-1}$ Fwt.

Peroxidase enzyme activity (POX; Enzyme Code. 1.11.1.7) was assayed following the method of Cvikrova et al. [41] with minor modifications [38]. For the analysis, $100 \mathrm{~mL}$ of the homogenate (obtained as above) was added to $3 \mathrm{~mL}$ of the reaction mixture $\left(50 \mathrm{mmol} \mathrm{L}^{-1}\right.$ Na-phosphate, $5 \mathrm{mmol} \mathrm{L}^{-1} \mathrm{H}_{2} \mathrm{O}_{2}, 13 \mathrm{mmol} \mathrm{L}^{-1}$ guaiacols, and $\mathrm{pH}$ 6.5). Activity was defined by the range of change in absorbance at $470 \mathrm{~nm}$ with a UV microplate spectrophotometer (Epoch, SN: 1611187, Winooski, VT, USA). One unit of POX was defined as a change of 0.1 absorbance unit per minute at $470 \mathrm{~nm}$. Activity is expressed as enzyme unit $\mathrm{mg}^{-1}$ Fwt.

Leaf mineral $\left(\mathrm{K}^{+}, \mathrm{Na}^{+}, \mathrm{Ca}^{2+}, \mathrm{Mg}^{2+}\right.$, and $\left.\mathrm{Cl}^{-}\right)$contents were determined according to the procedure made by Chapman and Pratt [42] with minor modifications [31]. Dry plant samples $(0.5 \mathrm{~g})$ were ground in porcelain crucibles. The porcelain crucibles were placed into a muffle furnace, and the temperature was gradually increased up to $500{ }^{\circ} \mathrm{C}$. Following cooling, the ash was dissolved in $5 \mathrm{~mL}$ of $2 \mathrm{~N}$ hydrochloric acid. After $30 \mathrm{~min}$, the volume was made up to $50 \mathrm{~mL}$ with distilled $\mathrm{H}_{2} \mathrm{O}$, and the supernatant was filtered through Whatman No.42 filter paper. The resulting supernatant containing $\mathrm{Na}^{+}, \mathrm{K}^{+}, \mathrm{Ca}^{+2}$, and $\mathrm{Mg}^{+2}$ ions were assessed by Inductively Coupled Plasma (ICP, Perkin Elmer). Chloride was determined using ion chromatography after the filtration through Whatman No.42 filter paper.

Duncan's multiple range test (DMRT) was used to evaluate the data using SPSS 22 (ANOVA test) at a significance level of $p \leq 0.05$ using. Data are presented as a mean value \pm with standard error. 


\section{Results}

Strawberry plant growth, fruit properties, biochemical parameters, and mineral contents were significantly affected by all salinity levels. The crown fresh and dry weights of strawberry plants in saline conditions were significantly lower in plants grown alone in saline conditions when compared to those of plants grown in combination with P. oleracea under the same conditions. For example, the crown fresh weights of the plants were 55.16, 37.62 , and 35.16 g plant $^{-1}$ grown alone in $\mathrm{S}_{30}, \mathrm{~S}_{60}$, and $\mathrm{S}_{90} \mathrm{mmol} \mathrm{L}^{-1} \mathrm{NaCl}$ conditions, respectively. When plants were grown in combinations with P. oleracea, their conditions were significantly improved at all $\mathrm{NaCl}$ conditions. The fresh weights of plants increased to $64.38,44.76$, and 44.49 plant $^{-1}$ at the $\mathrm{SP}_{30}, \mathrm{SP}_{60}$, and $\mathrm{SP}_{90} \mathrm{mmol} \mathrm{L}^{-1} \mathrm{NaCl}$ conditions, respectively (Table 1). Similar improvements were recorded for the dry weights of plants (Table 1). In general, the combination of companion plants (P. oleracea) was found to be effective in increasing the Fwt and Dwt under each $\mathrm{NaCl}$ condition.

Table 1. Growth and physiological parameters of strawberry plants grown alone or in combination with P. oleracea at differing $\mathrm{NaCl}$ levels.

\begin{tabular}{ccccc}
\hline Treatments & Crown Fwt (g Plant $\left.{ }^{-1}\right)$ & Crown Dwt (g Plant $\left.^{-1}\right)$ & EL (\%) & SC (mmol m $^{-\mathbf{2}} \mathbf{s}^{-\mathbf{1})}$ \\
\hline $\mathrm{S}_{0}$ & $85.32 \pm 4.17^{\mathrm{a}}$ & $18.39 \pm 0.70^{\mathrm{a}}$ & $11.90 \pm 0.77^{\mathrm{e}}$ & $241.98 \pm 4.29^{\mathrm{a}}$ \\
$\mathrm{S}_{30}$ & $55.16 \pm 5.30^{\mathrm{b}}$ & $12.71 \pm 1.40^{\mathrm{b}}$ & $15.61 \pm 0.57^{\mathrm{c}}$ & $183.26 \pm 8.19^{\mathrm{c}}$ \\
$\mathrm{S}_{60}$ & $37.62 \pm 2.70^{\mathrm{d}}$ & $10.00 \pm 1.07^{\mathrm{d}}$ & $21.84 \pm 1.06^{\mathrm{b}}$ & $127.64 \pm 8.39^{\mathrm{d}}$ \\
$\mathrm{S}_{90}$ & $35.16 \pm 1.90^{\mathrm{d}}$ & $9.39 \pm 0.69^{\mathrm{d}}$ & $25.34 \pm 0.92^{\mathrm{a}}$ & $94.10 \pm 3.83^{\mathrm{e}}$ \\
$\mathrm{SP}_{0}$ & $85.57 \pm 4.46^{\mathrm{a}}$ & $19.09 \pm 0.91^{\mathrm{a}}$ & $11.07 \pm 0.45^{\mathrm{e}}$ & $260.38 \pm 8.81^{\mathrm{a}}$ \\
$\mathrm{SP}_{30}$ & $64.38 \pm 5.01^{\mathrm{b}}$ & $14.77 \pm 1.08^{\mathrm{b}}$ & $11.10 \pm 0.95^{\mathrm{e}}$ & $230.80 \pm 5.48^{\mathrm{b}}$ \\
$\mathrm{SP}_{60}$ & $44.76 \pm 1.67^{\mathrm{c}}$ & $11.23 \pm 0.22^{\mathrm{c}}$ & $13.84 \pm 1.04^{\mathrm{d}}$ & $181.60 \pm 4.65^{\mathrm{c}}$ \\
$\mathrm{SP}_{90}$ & $44.49 \pm 2.69^{\mathrm{c}}$ & $11.16 \pm 0.59^{\mathrm{c}}$ & $15.32 \pm 1.03^{\mathrm{c}}$ & $131.08 \pm 5.51^{\mathrm{c}}$ \\
\hline
\end{tabular}

Significance level at $p \leq 0.05$ was determined for the salt treatment using Duncan's multiple range test. Different letters in each column indicate statistical differences. S: a strawberry grown alone; SP: the strawberry and P. oleracea companionship; EL: electrolyte leakage; SC: stomatal conductivity.

EL is considered an important criterion for salt stress parameters. EL was increased with increasing levels of salt. For example, leaf EL was found to be 11.90 and $11.07 \%$ at $\mathrm{S}_{0}$ and $\mathrm{SP}_{0}$, respectively. Increases of EL were trended from 15.61 to $25.34 \%$ with respect to conditions from $S_{30}$ to $S_{90}$, respectively. When P. oleracea was accompanied with strawberry plants in the $\mathrm{NaCl}$ conditions, the increase of $\mathrm{EC}$ was so minimal that only 11.10 and $15.32 \%$ were recorded at $\mathrm{SP}_{30}$ and $\mathrm{SP}_{90}$, respectively; see Table 1.

Stomatal conductivity in saline conditions was gradually decreased as the concentration of $\mathrm{NaCl}$ increased in plants grown alone in saline conditions (Table 1). However, the cultivation of $P$. oleracea improved the SC of strawberry plants under all $\mathrm{NaCl}$ conditions when compared to those grown alone in saline conditions. The improvement of SC was evident in that the increases were from 183.26 to $230.80 \%$ from $\mathrm{S}_{30}$ to $\mathrm{SP}_{30}$ cultivation conditions, respectively. At the higher $\mathrm{NaCl}$ concentrations of $\mathrm{S}_{90}$ and $\mathrm{SP}_{90}$, the $\mathrm{SC}$ was still improved with a lesser efficiency from 94.10 to $131.08 \%$, respectively.

The average fruit weight and yield of strawberry plants under $\mathrm{NaCl}$ conditions were reduced in plants grown alone, but the co-cultivation of strawberry plants with $P$. oleracea increased the average and total fruit weight (Table 2).

The employment of $P$. oleracea not only increased the crop yield and physiological parameters but also improved the quality of fruits in terms of lycopene and vitamin $C$ contents. Lycopene and vitamin $C$ contents were gradually decreased as the concentration of $\mathrm{NaCl}$ increased. Again, the employment of P. oleracea increased the lycopene and vitamin $\mathrm{C}$ at all $\mathrm{NaCl}$ levels (Table 2). For example, the remarkable effect was more evident at the $90 \mathrm{mmol} \mathrm{L}^{-1} \mathrm{NaCl}$ conditions, as the both lycopene and vitamin $\mathrm{C}$ contents were increased when grown with $P$. oleracea as compared to those of plants grown alone in saline conditions. 
Table 2. Yield and some fruit properties of strawberry plants grown alone or in combination with P. oleracea at differing $\mathrm{NaCl}$ levels.

\begin{tabular}{|c|c|c|c|c|c|}
\hline Treatments & $\begin{array}{c}\text { Average Fruit } \\
\text { Weight (g Plant }^{-1} \text { ) }\end{array}$ & Yield (g Plant ${ }^{-1}$ ) & Lycopene (mg kg ${ }^{-1}$ Fwt) & Vitamin C (mg kg ${ }^{-1}$ Fwt) & TSS (\%) \\
\hline $\mathrm{S}_{0}$ & $18.53 \pm 0.24^{\mathrm{a}}$ & $214.76 \pm 25.26^{\mathrm{a}}$ & $37.98 \pm 1.61^{\mathrm{a}}$ & $49.87 \pm 2.48^{\mathrm{a}}$ & $8.80 \pm 0.22^{a}$ \\
\hline $\mathrm{S}_{30}$ & $14.96 \pm 0.58^{c}$ & $132.85 \pm 19.44^{c}$ & $35.27 \pm 1.29^{a}$ & $45.07 \pm 2.55^{c}$ & $6.80 \pm 0.25^{b}$ \\
\hline $\mathrm{S}_{60}$ & $9.80 \pm 1.25^{\mathrm{e}}$ & $83.76 \pm 15.20^{\mathrm{d}}$ & $27.52 \pm 1.13^{b}$ & $36.79 \pm 1.30^{\mathrm{d}}$ & $5.80 \pm 0.24$ \\
\hline $\mathrm{S}_{90}$ & $5.60 \pm 0.58^{f}$ & $31.53 \pm 5.40^{\mathrm{e}}$ & $16.56 \pm 1.61^{\mathrm{c}}$ & $32.53 \pm 0.81^{\mathrm{e}}$ & $5.20 \pm 0.25^{e}$ \\
\hline $\mathrm{SP}_{0}$ & $19.09 \pm 0.52^{\mathrm{a}}$ & $229.40 \pm 17.46^{\mathrm{a}}$ & $37.20 \pm 1.45^{\mathrm{a}}$ & $51.88 \pm 1.89^{\mathrm{a}}$ & $9.00 \pm 0.20^{\circ}$ \\
\hline $\mathrm{SP}_{30}$ & $16.94 \pm 0.54^{b}$ & $164.80 \pm 23.99^{b}$ & $34.87 \pm 1.95^{\mathrm{a}}$ & $47.19 \pm 1.04^{\mathrm{a}}$ & $7.40 \pm 0.17^{b}$ \\
\hline $\mathrm{SP}_{60}$ & $15.74 \pm 0.53^{c}$ & $147.57 \pm 25.67^{c}$ & $33.93 \pm 1.82^{\mathrm{a}}$ & $41.36 \pm 1.70^{\mathrm{c}}$ & $5.90 \pm 0.20^{c}$ \\
\hline $\mathrm{SP}_{90}$ & $12.65 \pm 0.73^{\mathrm{d}}$ & $94.00 \pm 8.91^{\mathrm{d}}$ & $28.55 \pm 1.31^{b}$ & $43.12 \pm 2.51^{\mathrm{c}}$ & $5.60 \pm 0.19$ \\
\hline
\end{tabular}

Significance level at $p \leq 0.05$ was determined for the salt treatment using Duncan's multiple range test. Different letters in each column indicate statistical differences. S: a strawberry grown alone; SP: the strawberry and P. oleracea companionship; TSS: total soluble solids.

Unlike other parameters, the TSS contents of the fruits in saline conditions were significantly lowered. The co-cultivation of $P$. oleracea did not significantly improve the conditions of strawberry plants (Table 2).

Chl- $a$ and Chl- $b$ were significantly affected by salinity at the $\mathrm{S}_{60}$ and $\mathrm{S}_{90} \mathrm{mmol} \mathrm{L}^{-1}$ $\mathrm{NaCl}$ levels $(p \leq 0.05)$. For example, the Chl- $a$ and Chl- $b$ were determined as 0.70 and $0.36 \mathrm{mg} \mathrm{g}^{-1}$ Fwt, respectively, at $\mathrm{S}_{90} \mathrm{mmol} \mathrm{L}^{-1} \mathrm{NaCl}$ levels in strawberry plants. The positive effects of P. oleracea on the Chl- $a$ and Chl- $b$ contents at $\mathrm{SP}_{90} \mathrm{mmol} \mathrm{L}^{-1} \mathrm{NaCl}$ were evident, as the Chl- $a$ and Chl- $b$ contents were 1.01 and $0.51 \mathrm{mg} \mathrm{g}^{-1} \mathrm{Fwt}$, respectively, in strawberry plants (Figure 2A,B).
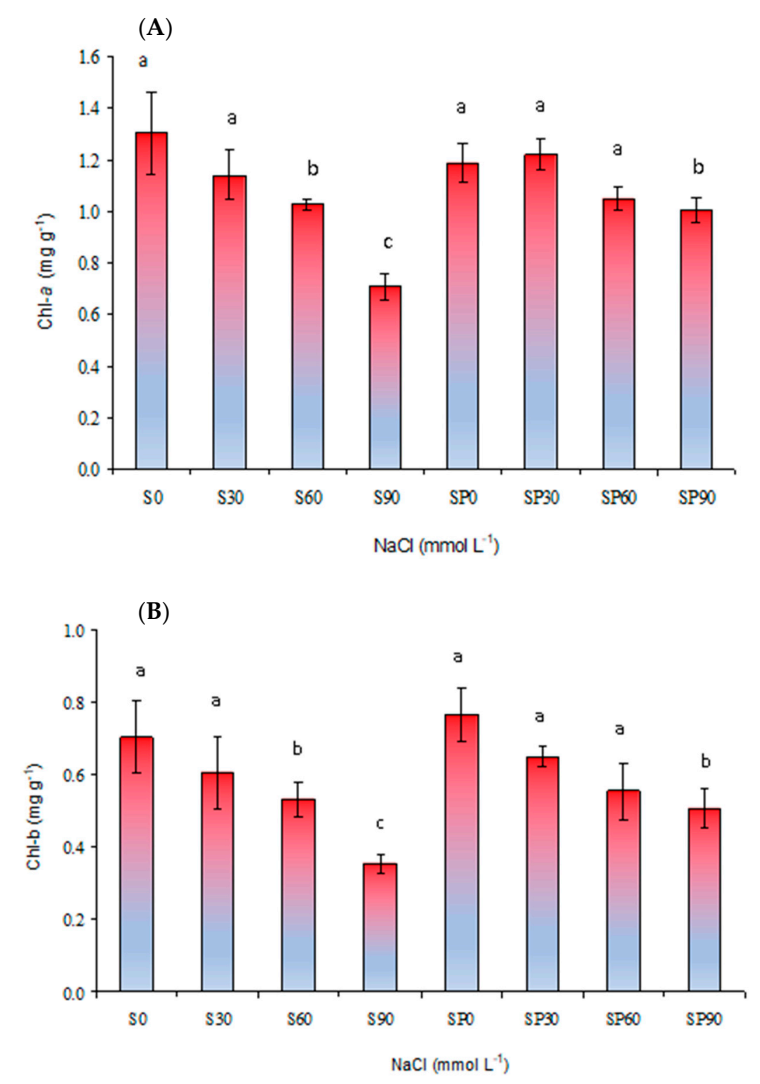

Figure 2. Leaf Chl- $a(\mathbf{A})$ and Chl- $b(\mathbf{B})$ contents of strawberry plants grown alone or in combination with P. oleracea at differing $\mathrm{NaCl}$ levels $\left(0,30,60\right.$, and $\left.90 \mathrm{mmol} \mathrm{L}^{-1}\right)$. S: a strawberry grown alone; SP: the strawberry and P. oleracea companionship; TSS: total soluble solids. 
Leaf proline content significantly increased as the concentration of $\mathrm{NaCl}$ levels increased as a response to salinity stress. $(p \leq 0.05)$; see Figure 3A. The highest proline level was determined as $13.77 \mu \mathrm{mol} \mathrm{g}^{-1}$ Fwt with the $\mathrm{S}_{90} \mathrm{mmol} \mathrm{L}^{-1} \mathrm{NaCl}$ treatment, whereas at the $\mathrm{SP}_{90}$ condition, the proline level decreased to $4.40 \mu \mathrm{mol} \mathrm{g}^{-1}$. Therefore, the combination of P. oleracea not only improved the physiological and biochemical conditions of strawberry plants but also reduced the stress metabolite levels.
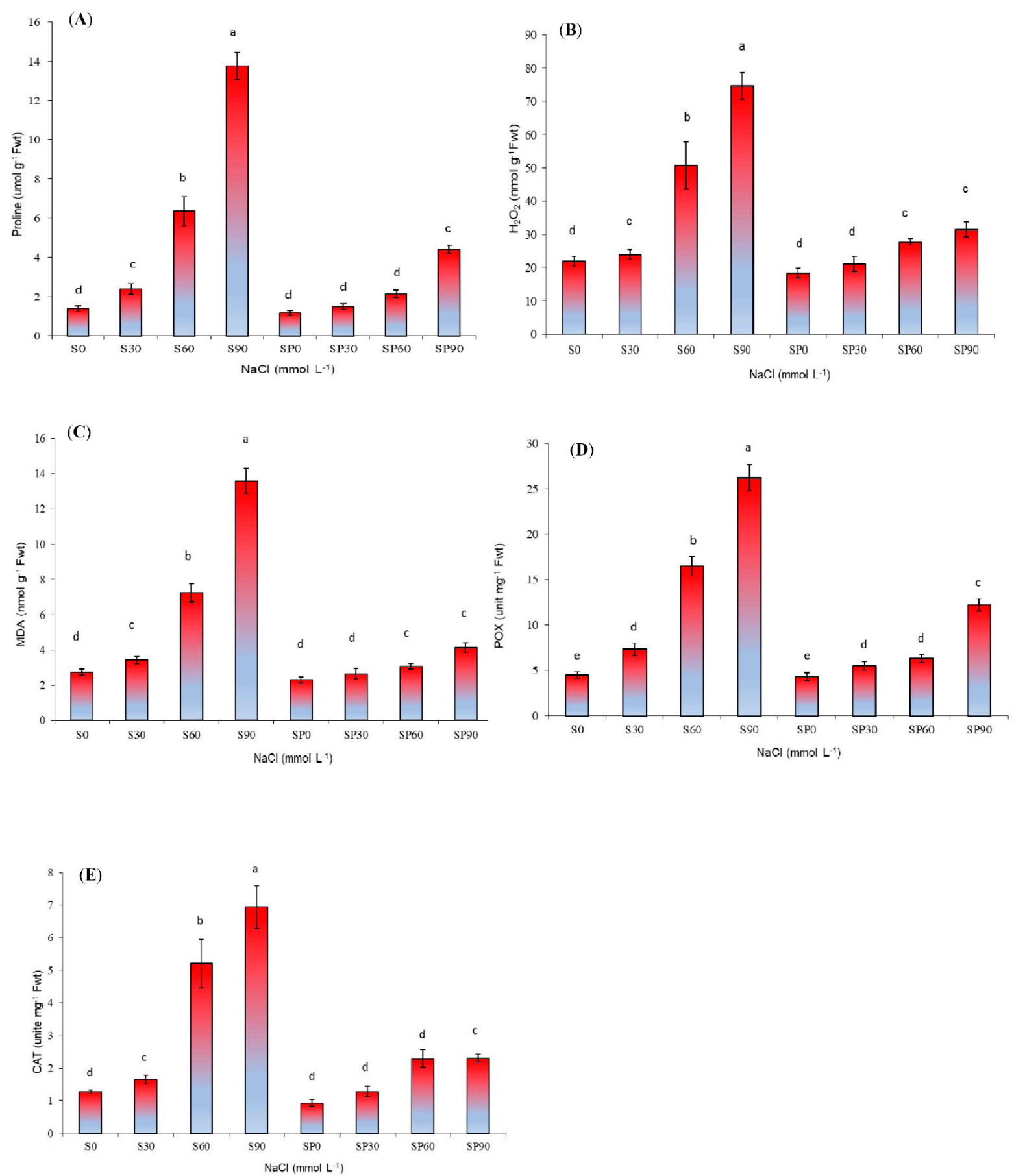

Figure 3. Proline (A), $\mathrm{H}_{2} \mathrm{O}_{2}$ (B), and malondialdehyde (MDA) (C) contents; peroxidase enzyme activity (POX) (D) and catalase enzyme activity (CAT) (E) antioxidant enzyme contents of strawberry plants grown alone or in combination with P. oleracea at differing $\mathrm{NaCl}$ levels $\left(0,30,60\right.$, and $\left.90 \mathrm{mmol} \mathrm{L}^{-1}\right)$. S: a strawberry grown alone; SP: the strawberry and P. oleracea companionship; TSS: total soluble solids. 
The companionship of P. oleracea had a remarkable effect to reduce the impact of $\mathrm{NaCl}$ stress in strawberry plants. Again, leaf $\mathrm{H}_{2} \mathrm{O}_{2}$ and MDA contents increased with the increasing levels of salt stress. The highest $\mathrm{H}_{2} \mathrm{O}_{2}$ and MDA levels were determined as 74.72 and $13.58 \mathrm{nmol} \mathrm{g}^{-1} \mathrm{Fwt}$, respectively, at the $\mathrm{S}_{90} \mathrm{mmol} \mathrm{L}^{-1} \mathrm{NaCl}$ level. The co-cultivation of $P$. oleracea with strawberry plants reduced the contents of $\mathrm{H}_{2} \mathrm{O}_{2}$ and MDA levels down to 31.56 and $4.15 \mathrm{nmol} \mathrm{g}^{-1}$ Fwt, respectively (Figure 3B,C).

POX and CAT antioxidant enzymes showed parallel patterns to those of previous parameters. The co-cultivation of $P$. oleracea significantly decreased antioxidant enzyme levels at the 60 and $90 \mathrm{mmol} \mathrm{L}^{-1} \mathrm{NaCl}$ conditions, (Figure 3D,E).

\section{Leaf Mineral Contents}

The concentrations of beneficial ions such as those of $\mathrm{K}^{+}$and $\mathrm{Ca}^{2+}$ decreased with the increases in salinity levels in strawberry plants. The lowest $\mathrm{K}^{+}$and $\mathrm{Ca}^{2+}$ ions were determined at the $\mathrm{S}_{90}$ level. The leaf $\mathrm{Mg}^{2+}$ content was not significantly affected upon $\mathrm{NaCl}$ stress. P. oleracea co-cultivation with strawberry plants enhanced the $\mathrm{Mg}^{2+}$ ion level at $\mathrm{NaCl}$ treatments; see Table 3. Under saline conditions, gradual increases of $\mathrm{Na}^{+}$and $\mathrm{Cl}^{-}$ions were evident in strawberry plants grown at increasing $\mathrm{NaCl}$ salinity, but the employment of $P$. oleracea significantly decreased the $\mathrm{Na}^{+}$and $\mathrm{Cl}^{-}$ion contents; Table 3 .

Table 3. Strawberry leaf mineral contents of strawberry plants grown alone or in combination with P. oleracea at differing $\mathrm{NaCl}$ levels.

\begin{tabular}{cccccc}
\hline Treatments & $\mathbf{K}^{+} \mathbf{( \% )}$ & $\mathbf{C a}^{\mathbf{2 +}} \mathbf{( \% )}$ & $\mathbf{M g}^{\mathbf{2 +}} \mathbf{( \% )}$ & $\mathbf{N a}^{+} \mathbf{( \% )}$ & $\mathbf{C l}^{-\mathbf{( \% )}}$ \\
\hline $\mathrm{S}_{0}$ & $2.32 \pm 0.10^{\mathrm{a}}$ & $2.39 \pm 0.13^{\mathrm{a}}$ & $0.32 \pm 0.03^{\mathrm{a}}$ & $0.17 \pm 0.04^{\mathrm{e}}$ & $0.35 \pm 0.01^{\mathrm{d}}$ \\
$\mathrm{S}_{30}$ & $1.82 \pm 0.08^{\mathrm{b}}$ & $1.97 \pm 0.11^{\mathrm{a}}$ & $0.28 \pm 0.03^{\mathrm{a}}$ & $0.32 \pm 0.02^{\mathrm{d}}$ & $0.67 \pm 0.03^{\mathrm{d}}$ \\
$\mathrm{S}_{60}$ & $1.41 \pm 0.06^{\mathrm{c}}$ & $1.86 \pm 0.04^{\mathrm{b}}$ & $0.29 \pm 0.02^{\mathrm{a}}$ & $0.69 \pm 0.05^{\mathrm{b}}$ & $2.09 \pm 0.29^{\mathrm{b}}$ \\
$\mathrm{S}_{90}$ & $1.02 \pm 0.05^{\mathrm{e}}$ & $1.72 \pm 0.03^{\mathrm{b}}$ & $0.28 \pm 0.03^{\mathrm{a}}$ & $1.09 \pm 0.03^{\mathrm{a}}$ & $3.69 \pm 0.23^{\mathrm{a}}$ \\
$\mathrm{SP}_{0}$ & $2.42 \pm 0.11^{\mathrm{a}}$ & $2.25 \pm 0.06^{\mathrm{a}}$ & $0.35 \pm 0.02^{\mathrm{a}}$ & $0.09 \pm 0.01^{\mathrm{e}}$ & $0.25 \pm 0.05^{\mathrm{d}}$ \\
$\mathrm{SP}_{30}$ & $2.27 \pm 0.06^{\mathrm{a}}$ & $2.15 \pm 0.13^{\mathrm{a}}$ & $0.33 \pm 0.03^{\mathrm{a}}$ & $0.19 \pm 0.03^{\mathrm{e}}$ & $0.46 \pm 0.03^{\mathrm{d}}$ \\
$\mathrm{SP}_{60}$ & $1.78 \pm 0.15^{\mathrm{b}}$ & $2.15 \pm 0.25^{\mathrm{a}}$ & $0.34 \pm 0.03^{\mathrm{a}}$ & $0.31 \pm 0.05^{\mathrm{d}}$ & $1.16 \pm 0.10^{\mathrm{c}}$ \\
$\mathrm{SP}_{90}$ & $1.66 \pm 0.09^{\mathrm{b}}$ & $2.14 \pm 0.11^{\mathrm{a}}$ & $0.31 \pm 0.02^{\mathrm{a}}$ & $0.49 \pm 0.08^{\mathrm{c}}$ & $1.29 \pm 0.06^{\mathrm{c}}$
\end{tabular}

Significance level at $p \leq 0.05$ was determined for the salt treatment using Duncan's multiple range test. Different letters in each column indicate statistical differences. S: a strawberry grown alone; SP: the strawberry and P. oleracea companionship.

\section{Discussion}

Salinity stress is one of the most devastating issues that damages crop plants in terms of quantity and quality. Increased salinity levels not only damage plants during vegetative stages but also negatively affect reproductive stages. Under salt stress, $\mathrm{Na}^{+}$is extensively accumulated in the shoots and roots of cultivars and $\mathrm{K}^{+}$content is decreased [43]. Quality parameters such as vitamin contents, aromatic substances, and pigments are remarkably reduced. Leaf proline content, as a response to stress, tends to increase. Increasing proline content under salinity conditions indicates the adverse effects of osmotic stress on the plant. Proline and soluble carbohydrates (also known as compatible solutes) are expected to be accumulated under salinity in strawberry [44]. This can be considered to be a criterion for stress tolerance [45]. This study showed that $P$. oleracea in combination with strawberry decreased proline levels under salinity along with the reduction of $\mathrm{Na}^{+}$and $\mathrm{Cl}^{-}$ion levels by reducing the toxic levels of salt ions. P. oleracea gave promising results on strawberry plants grown at different $\mathrm{NaCl}$ stress levels $\left(0,30,60\right.$, and $\left.90 \mathrm{mmol} \mathrm{L}^{-1}\right)$. It is important to note that peat has a high bulk density. For example, Nugraha et al. [46] stated that capillary water movement had a very critical role in supplying water to the rooting zones of crop plants or the top parts of the soil. They reported that the rate of capillary water movement progressively corresponded to the increase in bulk density. Farina et al. [47] also stated that $\mathrm{NaCl}$ accumulation in peat mulching was much lesser than that of soil. They stated that if the porosity in the surface layers became small enough, irrigation or raindrops could plug macropores in the surface. They either block main avenues for water and roots to move 
through the soil or they form a cement-like surface layer when the soil dries. The rock-solid upper layer or salt crust then restricts water movement and plant emergence. In our study, evaporation in the greenhouse was not high enough to build up $\mathrm{NaCl}$ accumulation in the top part of the soil. Therefore, no salt crust formation, which would have affected the results of our experimental findings, was observed.

Mozafari et al. [48] stated that salinity negatively affected the growth parameters, pigment content, and membrane stability, as well as disturbing the ionic balance in plants. For example, Saied et al. [49] stated that strawberry was considered to be a saline-sensitive plant. Many physiological and biochemical parameters deteriorated. This both directly and indirectly led to diminished productivity in plants [50]. We determined that fresh weight, dry weight, stomatal conductance, fruit average weight, fruit total yield, chlorophyll (Chl- $a$ and Chl- $b$ ), total soluble solids, lycopene content, vitamin $C$ content, and leaf mineral content $\left(\mathrm{K}^{+}\right.$and $\left.\mathrm{Ca}^{2+}\right)$ of strawberry plants significantly decreased with increasing $\mathrm{NaCl}$ levels. Strawberry plants grown in companionship with P. oleracea improved the condition of plants, and much lesser reductions in terms of total yield and quality were evident. The positive effect on strawberry growth was quite remarkable. The leaf electrolyte, proline, malondialdehyde, $\mathrm{H}_{2} \mathrm{O}_{2}$ contents, catalase enzyme activities, nd peroxidase enzyme activities, and leaf mineral contents $\left(\mathrm{Na}^{+}\right.$and $\left.\mathrm{Cl}^{-}\right)$of strawberry plants increased with an increasing level of salinity. The companion plants helped strawberry plants by reducing toxic ion levels, antioxidant enzyme levels, and stress metabolites. With the improvement of those parameters, electrolyte leakage and stomatal conductance were also improved, and this was reflected in the quality of fruits in terms of lycopene and vitamin $C$ contents. This study proved that mixed planting with P. oleracea in saline conditions was an effective phytoremediation technique that might significantly increase the yield production and quality of strawberry. Similar findings were also made for $S$. soda plants by Karakas [51] who suggested that the improvement of tomato plants via companion plants under salt stress $\left(1.3\right.$ and $\left.6.5 \mathrm{dS} \mathrm{m}^{-1}\right)$ was achieved with the synthesis of substances used for fruit development instead of building up substances for mechanisms of stress tolerance. It is important to note that synthesizing stress metabolites and antioxidant enzymes is quite costly for plants to cope with abiotic or biotic stress factors [17]. Instead of generating crop plants that can combat stress factors, the strategy that involves removing stress factors would be much appreciated. Any genetic modifications or biochemical approaches that increase the removing capacity of toxic ions or compounds from the soil habitat would be an environmentally friendly approach and a safe strategy. For example, Grafienberg et al. [52] and Karakas et al. [51] stated that reductions in stress metabolites and the uptake of toxic ions enabled tomato plants to use more energy to build up organic components such as lycopene and proteins instead of producing substances for defense mechanisms. In this study, salinity stress resulted in a reduction in vitamin $C$ content and lycopene contents in strawberry. Jamalian et al. [53] showed that salinity reduced the vitamin $C$ content of strawberries, which was in line with the results of the present study. The decrease in the vitamin C content of fruits at high salinity levels can be attributed to the decrease in carbohydrate (sugar) production caused by the decrease in photosynthesis required for vitamin $C$ biosynthesis.

Yaghubi et al. [44] reported that MDA concentration was also high in strawberry plants at salt stress conditions. They reported that reactive oxygen species (ROS) production was muck higher than the scavenging capacity of antioxidant enzymes. The dismutation of $\mathrm{O}_{2}{ }^{-2}$ into $\mathrm{H}_{2} \mathrm{O}_{2}$ and $\mathrm{O}_{2}$ was reported to increase $\mathrm{H}_{2} \mathrm{O}_{2}$ concentration [54]. This was observed by a higher $\mathrm{H}_{2} \mathrm{O}_{2}$ content in salt-stressed strawberry plants than in control plants. Since $\mathrm{H}_{2} \mathrm{O}_{2}$ was accompanied by an increase in the key antioxidant enzymes such as CAT, POD, and superoxide dismutase (SOD), a reduction of $\mathrm{H}_{2} \mathrm{O}_{2}$ was achieved. In our methodology, we achieved the decrease of stress metabolites while suppressing the antioxidant enzymes via the use of $P$. oleracea plants. Though antioxidant enzymes such as CAT, POD, and SOD are known to substantially reduce the levels of $\mathrm{O}_{2}{ }^{-}$and $\mathrm{H}_{2} \mathrm{O}_{2}$ in plants and play a vital role in plant defense against oxidative stress [55], the increase of these enzymes might 
interfere with the chemical compounds involved in quality parameters such as lycopene and vitamin C. With the use of P. oleracea, we were able to reduce stress metabolites and toxic ions, reduced further damages to cell components, and increased the quality-related compounds without increasing defense-related antioxidant compounds. This saved the energy to be used for defense responses, and this saved energy could be used to increase metabolic functions and quality parameters.

\section{Conclusions}

Strawberry cultivation has become popular recently, and this has led to an increase in cultivated areas. These areas have become saline-polluted, saline-prone, and salineprevalent. Since strawberry is a salt-sensitive plant, it is easily affected by a mild or moderate level of salinity. A very low level of $\mathrm{NaCl}$ could reduce crop yield and reduce the quality of fruits.

In this study, strawberry seedlings were grown alone or in combination with $P$. oleracea under differing $\mathrm{NaCl}$ concentrations. Strawberry seedlings under increasing $\mathrm{NaCl}$ salinity were negatively affected in terms of physiological, morphological, and biochemical parameters. Defending plants synthesized various stress metabolites such as proline, MDA, $\mathrm{H}_{2} \mathrm{O}_{2}$, and antioxidant enzymes to ease the negative effects of $\mathrm{NaCl}$ toxicity. However, increases of these metabolites were negatively correlated with quality-related metabolites such as vitamin $C$ and lycopene. The cultivation of strawberry plants with $P$. oleracea plants reduced the concentrations of stress metabolites and antioxidant enzyme levels, as well as indirectly contributing to increases of vitamin $C$ and lycopene contents.

We suggest that the employment of P. oleracea would remediate the conditions of strawberry parameters by accumulating $\mathrm{Na}^{+}$and $\mathrm{Cl}^{-}$ions, thus causing reductions in the synthesis of stress metabolites. The use of P. oleracea is a quite practical and environmentally friendly approach where salinity is prevalent. P. oleracea has a high potential that could be used in high saline and in other environmental stress conditions.

Author Contributions: Conceptualization, S.K., M.D. and I.B.; methodology, S.K., I.B. and M.D.; software, S.K. and M.D.; validation, S.K., I.B. and M.D.; formal analysis, S.K. and M.D.; investigation, S.K., I.B. and M.D.; resources, S.K., I.B. and M.D.; data curation, S.K.; writing-original draft preparation, S.K.; writing-review and editing, M.D. and I.B.; visualization, S.K., I.B. and M.D.; supervision, S.K.; project administration, S.K.; funding acquisition, S.K. All authors have read and agreed to the published version of the manuscript.

Funding: This research was funded by Harran University Scientific Research Project (HUBAP), grant number 17247

Institutional Review Board Statement: Not applicable.

Informed Consent Statement: Not applicable.

Conflicts of Interest: The authors declare no conflict of interest.

\section{References}

1. Zhao, G.M.; Han, Y.; Sun, X.; Li, S.H.; Shi, Q.M.; Wang, C.H. Salinity increases secondary metabolites and enzyme activity in safflower. Ind. Crop. Prod. 2015, 64, 175-181.

2. Zhou, Y.; Tang, N.; Huang, L.; Zhao, Y.; Tang, X.; Wang, K. Effects of Salt Stress on Plant Growth, Antioxidant Capacity, Glandular Trichome Density, and Volatile Exudates of Schizonepeta tenuifolia Briq. Int. J. Mol. Sci. 2018, 19, 252. [CrossRef]

3. Hasanuzzaman, M.; Nahar, K.; Alam, M.M.; Bhowmik, P.C.; Hossain, M.A.; Rahman, M.M.; Prasad, M.N.V.; Ozturk, M.; Fujita, M. Potential use of halophytes to remediate saline soils. BioMed Res. Int. 2014, 2014, 589341. [CrossRef] [PubMed]

4. Menason, E.; Betty, T.; Vijayan, K.K.; Anbudurai, P.R. Modification of fatty acid composition in salt adopted Synechocystis 6803 cells. Ann. Biol. Res. 2015, 6, 4-9.

5. Flowers, T.J.; Colmer, T.D. Salinity tolerance in halophytes. New Phytol. 2008, 179, 945-963. [CrossRef] [PubMed]

6. Kader, M.A.; Lindberg, S. March Cytosolic calcium and pH signaling in plants under salinity. Plant. Signal. Behav. 2010, 5, 233-238. [CrossRef]

7. Hossain, M.D.; Inafuku, M.; Iwasaki, H.; Taira, N.; Mostofa, M.G.; Oku, H. Differential enzymatic defense mechanisms in leaves and root of two true mangrove species under long-term salt. Aquat. Bot. 2017, 142, 32-40. [CrossRef] 
8. Munns, R. Comparative physiology of salt and water stress. Plant Cell Environ. 2002, 25, 239-250. [CrossRef]

9. Acosta-Motos, J.R.; Ortuño, M.F.; Bernal-Vicente, A.; Diaz-Vivancos, P.; Sanchez-Blanco, M.J.; Hernandez, J.A. Plant Responses to Salt Stress: Adaptive Mechanisms. Agronomy 2017, 7, 18. [CrossRef]

10. Cheeseman, J. The evolution of halophytes, glycophytes and crops, and its implications for food security under saline conditions. New Phytol. 2014, 206. [CrossRef]

11. Meng, X.; Sui, J.Z.N. Mechanisms of salt tolerance in halophytes: Current understanding and recent advances. Open Life Sci. 2018, 13, 149-154. [CrossRef]

12. Aslam, R.; Bostan, N.; Amen, N.; Maria, M.; Safdar, W. A critical review on halophytes: Salt tolerant plants. J. Med. Plants Res. 2011, 5, 7108-7118.

13. Flowers, T.J.; Galal, H.K.; Bromham, L. Evolution of halophytes: Multiple originsof salt tolerance in land plants. Funct. Plant. Biol. 2010, 37, 604-612. [CrossRef]

14. Qadir, M.; Qureshi, R.H.; Ahmad, N. Amelioration of calcareous saline sodic soils through phytoremediation and chemical strategies. Soil Use Manag. 2002, 18, 381-385. [CrossRef]

15. Dikilitas, M.; Karakas, S. Salt as potential environmental Pollutants, their types, effects on plants, and approaches for their phytoremediation. In Plant Adaptation and Phytoremediation; Ashraf, M., Ozturk, M., Ahmad, M.S.A., Eds.; Springer: Berlin/Heidelberg, Germany, 2010; pp. 357-383.

16. Xing, J.C.; Dong, J.; Wang, M.V.; Liu, C.; Zhao, B.Q.; Wen, Z.G.; Zhu, X.M.; Ding, H.R.; Zhao, X.H.; Hong, L.Z. Effects of NaCl stress on growth of Portulaca oleracea and underlying mechanisms. Braz. J. Bot. 2019, 42, 217-226. [CrossRef]

17. Karakas, S.; Dikilitas, M.; Tipırdamaz, R. Phytoremediation of Salt-Affected Soils Using Halophytes. In: Grigore MN. (eds) Handbook of Halophytes. Springercham 2020, 1-18. [CrossRef]

18. De Lacerda, L.P.; Lange, L.C.; Costa França, M.G.; Diniz Leão, M.M. Growth and differential salinity reduction between Portulaca oleracea and Eichhornia crassipes in experimental hydroponic units. Env. Technol. 2018, 22, 1-9. [CrossRef]

19. Grieve, C.M.; Suarez, D.L. Purslane (Portulaca oleracea L.): A halophytic crop for drainage water reuse systems. Plant. Soil 1997, 192, 277-283. [CrossRef]

20. Karakas, S.; Çullu, M.A.; Dikilitas, M. In Vitro kosullarda halofit bitkilerden Salsola soda ve Portulaca oleracea' nın NaCl stresine karşı çimlenme ve gelisim durumları. Harran Tarım Ve Gıda Bilimleri Derg. 2015, 19, 66-74.

21. Folta, K.M.; Davis, T.M. Strawberry genes and genomics. Crit. Rev. Plant. Sci. 2006, 25, 399-415. [CrossRef]

22. Shulaev, V.; Korban, S.S.; Sosinski, B.; Abbott, A.G.; Aldwinckle, H.S.; Folta, K.M.; Iezzoni, A.; Main, D.; Arús, P.; Dandekar, A.M.; et al. Multiple models for rosaceae genomics. Plant. Physiol. 2008, 147, 985-1003. [CrossRef] [PubMed]

23. Neocleous, D.; Vasilakakis, M. Effects of $\mathrm{NaCl}$ stress on red raspberry (Rubus idaeus L. 'Autumn Bliss'). Sci. Hortic. 2007, 112, 282-289. [CrossRef]

24. Keutgen, A.; Pawelzik, E. Quality and nutritional value of strawberry fruit under long term salt stress. Food Chem. 2008, 107, 1413-1420. [CrossRef]

25. Jamalian, S.; Gholami, M.; Esna-Ashari, M. Abscisic acid-mediated leaf phenolic compounds, plant growth and yield is strawberry under different salt stress regimes. Theor. Exp. Plant. Physiol. 2013, 25, 291-299.

26. Garriga, M.; Muñoz, C.A.; Caligari, P.D.; Retamales, J.B. Effect of salt stress on genotypes of commercial (Fragaria $x$ ananassa) and Chilean strawberry (F. chiloensis). Sci. Hortic. 2015, 195, 37-47. [CrossRef]

27. Bohlin, C.; Holmberg, P. Peat dominating growing medium in Swedish horticulture. Acta Hortic. 2004, 644, 177-181. [CrossRef]

28. Bin Mohamad, H.; Zainorabidin, A.; Razali, S.; Zolkefle, S. Assessment for applicability of microwave oven in rapid determination of moisture content in peat soil. J. Eng. Sci. Technol. 2020, 15, 2110-2118.

29. Catania, P.; Comparetti, A.; De Pasquale, C.; Morello, G.; Vallone, M. Effects of the Extraction Technology on Pomegranate Juice Quality. Agronomy 2020, 10, 1483. [CrossRef]

30. Barrett, D.M.; Anthon, G. Lycopene content of calıfornia-grown tomato varieties. Acta Hortic. 2001, 542, 165-174. [CrossRef]

31. Karakas, S. Development of Tomato Growing in Soil Differing in Salt Levels and Effects of Companion Plants on Same Physiological Parameters and Soil Remediation. Ph.D. Thesis, University of Harran, Sanliurfa, Turkey, 2013.

32. Oz, A.T. Effects of two differrent temperatures on l-ascorbic acid content (Vitamin C), lenght of storage time and fruit quality. Bahce 2002, 31, 51-57.

33. Lutts, S.; Kinet, J.M.; Bouharmont, J. NaCl-induced senescence in leaves of rice (Oryza sativa L.) cultivars differing in salinity resistance. Ann. Bot. 1996, 78, 389-398. [CrossRef]

34. Karlidag, H.; Yildirim, E.; Turan, M. Role of 24-epibrassinolide in mitigating the adverse effects of salt stress on stomatal conductance, membrane permeability, and leaf water content, ionic composition in salt stressed strawberry (Fragaria $\times$ ananassa). Sci. Hortic. 2011, 130, 133-140. [CrossRef]

35. Arnon, D.L. A copper enzyme is isolated chloroplast polyphenol oxidase in Beta vulgaris. Plant. Physiol. 1949, 24, 1-15. [CrossRef] [PubMed]

36. Bates, L.S.; Waldren, R.P.; Teare, I.D. Rapid determination of free proline for water-stress studies. Plant. Soil 1973, 39, $205-207$. [CrossRef]

37. Velikova, V.; Yordanov, I.; Edreva, A. Oxidative stress and some antioxidant systems in acid raintreated bean plants: Protective role of exogenous polyamines. Plant. Sci. 2000, 151, 59-66. [CrossRef] 
38. Karakas, S.; Dikilitas, M.; Tipırdamaz, R. Biochemical and molecular tolerance of Carpobrotus acinaciformis L. halophyte plants exposed to high level of $\mathrm{NaCl}$ stress. Harran J. Agric. Food Sci. 2019, 23, 99-107.

39. Sairam, R.K.; Sexena, D. Oxidative stress and antioxidants in wheat genotypes: Possible mechanism of water stress tolerance. J. Agron. Crop. Sci. 2000, 184, 55-61. [CrossRef]

40. Milosevic, N.; Slusarenko, A.J. Active Oxygen Metabolism and Lignifications in The Hypersensitive Response in Bean. Physiol. Mol. Plant. Pathol. 1996, 49, 143-158. [CrossRef]

41. Cvikrova, M.; Hrubcova, M.; Vagner, M.; Machackova, I.; Eder, J. Phenolic acids and peroxidase activity in Alfalfa (Medicago sativa) embryogenic cultures after ethephon treatment. Plant. Physiol. 1994, 91, 226-233. [CrossRef]

42. Chapman, H.D.; Pratt, P.F. Methods of Analysis for Soils, Plants, and Waters; University of California, Division of Agricultural Sciences: Riverside, CA, USA, 1961.

43. Saidimoradi, D.; Ghaderi, N.; Javadi, T. Salinity stress mitigation by humic acid application in strawberry (Fragaria $x$ ananassa Duch.). Sci. Hortic. 2019, 256, 594. [CrossRef]

44. Yaghubi, K.; Ghaderi, N.; Vafaee, Y.; Javadi, T. Potassium silicate alleviates deleterious effects of salinity on two strawberry cultivars grown under soilless pot culture. Sci. Hortic. 2016, 213, 87-95. [CrossRef]

45. Munns, R.; Tester, M. Mechanisms of salinity tolerance. Annu. Rev. Plant. Biol. 2008, 59, 651-681. [CrossRef] [PubMed]

46. Nugraha, M.I.; Annisa, W.; Syaufina, L.; Anwar, S. Capillary water rise in peat soil as affected by various groundwater levels. Indones. J. Agric. Sci. 2016, 17, 75-83. [CrossRef]

47. Farina, E.; Allera, C.; Paterniani, T.; Palagi, M. Mulching as a technique to reduce salt accumulation in soilless culture. Acta Hortic. 2003, 609, 459-466. [CrossRef]

48. Mozafari, A.A.; Dedejani, S.; Ghaderi, N. Positive responses of strawberry (Fragaria $\times$ ananassa Duch.) explants to salicylic an iron nanoparticle application undersalinity conditions. Plant. Celltissue Organ. Cult. 2018, 134, 267-275. [CrossRef]

49. Saied, A.S.; Keutgen, A.J.; Noga, G. The influence of $\mathrm{NaCl}$ salinity on growth, yield and fruit quality of strawberry cvs. 'Elsanta'and 'Korona'. Sci. Hortic. 2005, 103, 289-303. [CrossRef]

50. Joseph, B.; Jini, D.; Sujatha, S. Insight into the role of exogenous salicylic acid on plants grown under salt environment. Asian J. Crop. Sci. 2010, 2, 226-235. [CrossRef]

51. Karakas, S.; Cullu, M.A.; Kaya, C.; Dikilitas, M. Halophytic companion plants improve growth and physiological parameters of tomato plants grown under salinity. Pak. J. Bot. 2016, 48, 21-28.

52. Grafienberg, A.; Botrini, L.; Giustiniani, L.; Filippi, F.; Curadi, M. Tomato growing in saline conditions with biodesalinating plants: Salsola soda and Portulaca oleracea. Acta Hortic. 2003, 609, 301-305. [CrossRef]

53. Jamalian, S.; Tehranifar, A.; Tafazoli, E.; Eshghi, S.; Davarynejad, G.H. Paclobutrazol application ameliorates the negative effect of salt stress on reproductive growth, yield, and fruit quality of strawberry plants. Hortic. Environ. Biotechnol. 2008, 49, 1-6.

54. Singh, R.; Flowers, T. Physiology and molecular biology of the effects of salinity on rice. Handb. Plant. Crop. Stress 2010, 901-942.

55. Ashraf, M. Biotechnological approach of improving plant salt tolerance using antioxidants as markers. Biotechnol. Adv. 2009, 27, 84. [CrossRef] [PubMed] 